\title{
Enhancing Rural Livelihoods Through Tourism Education and Strategic Partnerships: A Uganda Case Study
}

\author{
J. Michael Campbell
}

University of Manitoba

\section{K. MacKay}

Ryerson University

\section{Christine Dranzoa}

Makerere University

\section{Please Cite:}

Campbell, J. M., Mackay, K., Dranzoa, C. (2011). Enhancing rural livelihoods through tourism education and strategic partnerships: A Uganda case study. Tourism Analysis, 16(1), 5-17.

doi:10.3727/108354211X12988225899921

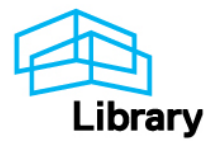




\title{
ENHANCING RURAL LIVELIHOODS THROUGH TOURISM EDUCATION AND STRATEGIC PARTNERSHIPS: A UGANDA CASE STUDY
}

\section{J. MICHAEL CAMPBELL,$*$ K. MACKAY,* and CHRISTINE DRANZOA $\dagger$}

*Health, Leisure, \& Human Performance Research Institute,

Kinesiology \& Recreation Management, University of Manitoba, Winnipeg, MB, Canaga

$\dagger$ Department of Wildlife and Animal Resources Management, Deputy Director of the School of Graduate Studies, Makerere University, Kampala, Uganda

\begin{abstract}
Recently, tourism has gained significant strides as a poverty reduction strategy for low income nations, including Uganda, where poor people constitute $61 \%$ of Uganda's population, living below US\$1 per day. In 2003, the Government of Uganda identified tourism as a priority export sector. This article provides a Uganda case study that focuses on enhancing rural livelihoods through tourism, specifically highlighting the interdependent themes of tourism training and partnership development as aims of a University of Manitoba-Makerere University cooperative program. Uganda is a country rich in natural and cultural resources with opportunities for sustainable tourism providing local impetus to support the conservation of wildlife and natural areas. The key to realizing this potential lies in the development of local capacity to research, manage, plan, interpret, and profit from the resources that are the foundation of sustainable tourism. The two universities are in partnership to develop a masters' degree in sustainable community tourism. Specifically the article describes the curriculum development process for a master's degree in sustainable community tourism at Makerere University, the creation of a strategic partners' network for sustainable tourism and biodiversity conservation, and the relationship between the two processes linking higher education and community development with sustainable tourism. Challenges faced by the Canadian and Ugandan project participants, as well as solutions, next steps for implementation, and future research opportunities are also discussed.
\end{abstract}

Key words: Poverty alleviation; Community tourism; Uganda; Education; Partnerships

Introduction

Recently, tourism has gained significant strides as a poverty reduction strategy for low income nations (United Nations World Tourism Organization [UNWTO], 2007). Although this idea is not new (de Kadt, 1979), it is once again receiving attention from governments, nongovernmental organizations (NGOs), and academics, alike. A recent volume on current themes in tourism, Propoor tourism: Who benefits? (Hall, 2007), brings attention to the range of opinions and critical de- 
bate surrounding the potential of tourism to be successful in this regard, and foster positive outcomes at the level intended. Poverty reduction is a central concern for Uganda, which has a per capita GNI of US\$250 (World Bank, 2003), and where poor people constitute $61 \%$ of Uganda's population, living below US\$1 per day, earning it a human development ranking of 113th out of 144 nations (United Nations Development Programme [UNDP], 2004). Concurring with UNWTO reports that tourism is a significant export for developing countries, a Government of Uganda report (2003) "Tourism Policy for Uganda" identifies tourism as a priority export sector that exceeds all others in GDP.

Uganda is a country rich in natural and cultural resources with opportunities for sustainable tourism providing local impetus to support the conservation of wildlife and natural areas. Once a prime tourist destination in Africa, Uganda tourism suffered dramatically after decades of internal conflict, during which time wildlife populations were decimated through widespread poaching. Now Uganda's wildlife populations are beginning to recover, security is increasing, and the country is once again welcoming tourists. The Government of Uganda's (2003) tourism policy and the draft report on "Sustainability Initiatives of the Uganda Wildlife Authority" (Government of Uganda, 2004) both identified the thoughtful development of tourism as crucial for conserving Uganda's wildlife while simultaneously sustaining the integrity of Uganda's diverse cultures. The key to realizing this potential lies in the development of local capacity to research, manage, plan, interpret, and profit from the resources that are the foundation of sustainable community-based tourism (Ashley, Roe, \& Goodwin, 2001). To achieve this symbiotic relationship between tourism and resource conservation, it is essential that local communities derive benefits from tourism visits. This in turn requires that local communities are equipped with the appropriate skills and abilities that will enable them to plan for, attract, and interact with tourists in a meaningful way, and derive economic benefits from the "wildlife capital" of the National Parks adjacent to their communities. The limitations of tourism as a poverty reduction strategy rest on this capacity building and its sustainability (Chok, Macbeth, \& Warren, 2007). The unique contribution of this project between the University of Manitoba (Canada) and Makerere University (Uganda) and the focus of this article is a threepronged approach involving graduate education, community tourism development, and strategic partnership network. Figure 1 illustrates the relationships among the project elements and their development, which forms the framework for describing this case study.

The University of Manitoba ( $\mathrm{U}$ of $\mathrm{M}$ ) in cooperation with Makerere University (MAK) in Uganda has initiated a 6-year program designed to address: a) weak institutional linkages between rural communities, NGOs, universities, government departments, and public policy makers; b) deficiencies in community-oriented professional skills in sustainable tourism and biodiversity conservation; and c) the need for interdisciplinary approaches in higher learning to address intertwined problems of biodiversity conservation and sustainable tourism development. An antipoverty tourism framework proffered by Zhao and Ritchie (2007) based on contemporary development practices identifies three key determinants: 1) opportunity for economic independence; 2) empowerment for influence in economic and political spheres; and 3) security as it relates to reducing health, economic, and natural risks. These factors are all components considered in this triad approach to enhance rural livelihoods through community tourism in Uganda. The two universities are in partnership to implement tourism community outreach through building and nurturing tourism networks at institutional, government, NGO, and community levels by developing a master's curriculum in Wildlife Tourism and Recreation Management. The partnership and master's program is based upon the premise that developing in-country expertise in Uganda will allow Uganda to better plan for, manage, and benefit from tourists who travel to see the primary tourist attraction in Uganda-the endangered mountain gorilla (Gorilla gorilla berengei).

This article focuses on the interdependent themes of tourism training and partnership development through the presentation of a case study documenting results from the first 2 years of the 6-year project. Specifically, the article addresses the creation of a strategic partners' network for 


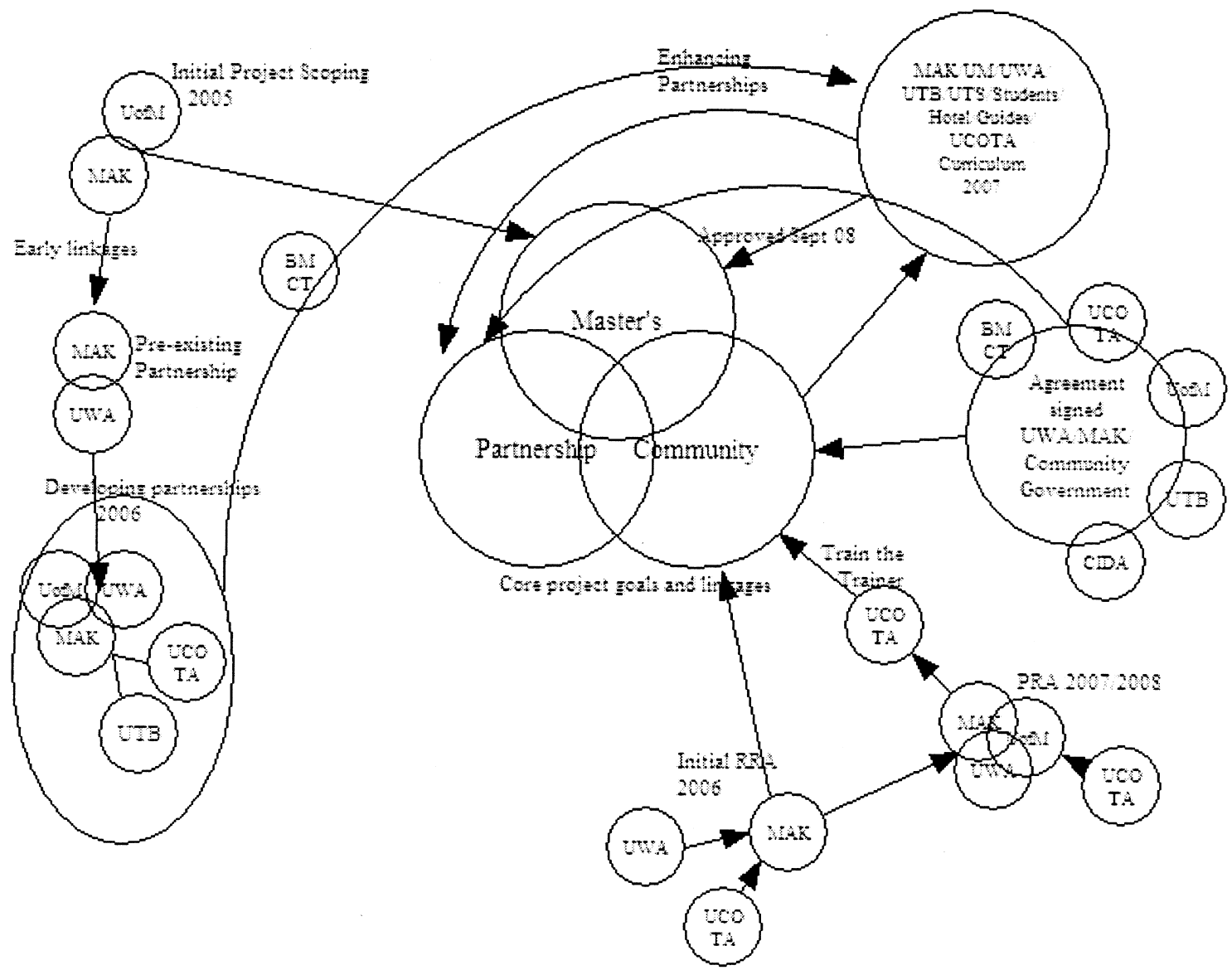

Figure 1. Relationship between CIDA project elements and their development. Note: Overlap indicates relative degree of resource sharing within project framework (i.e., does not indicate exclusivity of activity but rather relative level of cooperation).

sustainable tourism and biodiversity conservation, the curriculum development process for a master's degree in sustainable community tourism at Makerere University, and the relationship between the two processes linking higher education and community development with sustainable tourism.

\section{Background}

After over a decade of relative stability, wildlife numbers and international tourist arrivals to Uganda have begun to increase (Uganda Tourism Board [UTB], 2008). Uganda's capacity to manage these visitors is currently very limited at all levels and sectors of tourism, and to date has depended almost entirely upon outside expertise.
Lack of expertise in visitor management, market research, natural and cultural resource assessment, and monitoring is a serious impediment to sustainable tourism development. Regardless, enormous potential exists to utilize Uganda's rich natural and cultural heritage resources for sustainable tourism while providing a much needed local impetus to support their conservation. For instance, Uganda is home to one half of the world's endangered mountain gorillas and harbors over 1,000 species of birds, many of them rare Albertine endemics.

Tourism is the world's largest industry and forms the basis of many developing counties economic development plans, and is widely promoted 
as an engine of economic growth (Scheyvans \& Momsen, 2008). Tourism is also posited as providing incentives for the conservation of biodiversity and support for protected areas. In Uganda, tourism receipts represent $50 \%$ of the GNP and tourism is viewed as a key element in developing the country's economy and generating economic growth. Tourism also has been promoted in meeting conservation goals, such as enhancing protected areas support and, more recently as a poverty reduction strategy. In contrast to the cautionary approach of the 1970s and 1980s Ashley et al. (2001) note that tourism, when properly planned for and managed, can be an effective tourism strategy as it: has low barriers to entry; provides opportunities for women and youth; frequently occurs where other economic activity is limited; does not require a high degree of literacy; and provides opportunities for downstream linkages. A key to realizing these outcomes (both in terms of benefits to the poor and consequently in support of conservation goals) is the development of local capacity in tourism training, planning, and partnership.

The project described herein links higher education with community development, and the conservation of biological diversity in Uganda. The project's aims are consistent with the objectives of the Government of Uganda's (2003) new “Tourism Policy for Uganda" and the draft "Sustainability Initiatives for the Uganda Wildlife Authority" (Government of Uganda, 2004), and it complements the Canadian International Development Agency's (CIDA) current Pan African Nile Basin Initiative. The University of Manitoba and Makerere University are working in partnership with the Government of Uganda (e.g., Uganda Wildlife Authority and Uganda Tourist Board), private enterprises (through the Uganda Tourism Association), NGOs with complementary roles and responsibilities (e.g., the Uganda Community Tourism Association, Community Tourism Initiative of Uganda, and Care International in Uganda), and three communities bordering conservation areas. Together the aim is to stimulate private sector development (focused on the community level), address environmental issues, and promote good governance.

The Uganda Wildlife Authority (UWA) is re- sponsible for the conservation of Uganda's wildlife and protected areas in partnership with neighboring communities for the benefit of the people of Uganda and the global community. The Uganda Tourist Board (UTB) is the parastatal organization charged with marketing Uganda as a tourist destination. The Uganda Community Tourism Association (UCOTA) is an umbrella membership organization for community-based tourism enterprise in Uganda. Its mission is to spearhead sustainable community-based tourism through capacity building, marketing, advocacy, and enterprise development, and in support of the conservation of natural and cultural resources for enhanced livelihoods. Community-Based Tourism Initiative (COBATI) supports community-based tourism enterprises at the household level through capacity building. Care Uganda, a member of NGO Forum, emphasizes long-term development projects in agriculture, primary health care, population, and small enterprise development, most recently working with communities surrounding Bwindi National Park to establish environmentally sustainable enterprises.

Under the Poverty Eradication Action Plan (Government of Uganda, 2000), all sectors participate in transforming Uganda into a modern economy and contribute towards economic growth that is sustainable. The government's target is increased incomes, most especially for the rural poor people who depend on natural resources, through improved delivery of services by the state and communities. Through the Ministry of Tourism, Trade, and Industry, the Uganda Wildlife Authority (UWA) is invested with the custody of the wildlife resources, and has developed a strategy to facilitate tourism as an "export commodity" consumed at home. UWA is granting user rights to new emerging enterprises based on wildlife outside the protected areas, and it is promoting private initiatives to develop in support of the government's efforts to alleviate poverty in the rural areas by creating an enabling environment for economic growth and structural transformation. This is directly increasing opportunities for poor people to raise their incomes, in part through increased and more efficient private sector production of tourism-oriented goods and services that are consistent with environmental and natural resource 
use sustainability (Government of Uganda, 2003).

Another resource available for private sector development at the local level is the Community Conservation Initiative Fund, which earmarks $20 \%$ of park gate fees to community conservation projects. To date the ability of many communities to capitalize upon these opportunities has been hampered by a lack of understanding of how to develop proposals that reflect sustainability, community conservation goals, and their potential link to tourism initiatives based on local knowledge and resources. Indeed, the UWA has lamented the limited number of initiatives seeking to develop tourism-oriented goods and services through the Community Conservation Initiative Fund. The new master's program in Wildlife Tourism and Recreation Management at Makerere University will provide ongoing support (through training and student practica related to the local initiatives) to communities in developing tourism plans to derive enhanced livelihoods from natural and cultural resources, taking advantage of such programs.

\section{Need for Tourism Graduate Education}

While community-based tourism as a form of pro-poor tourism has been promoted with some success in East Africa (e.g., SNV funded Tanzanian Community Tourism Program) and in select areas of Uganda (e.g., Buhoma community walks), expansion of these previous initiatives to other communities in Uganda has been limited by the inadequate development of a local knowledge base and expertise capable of preparing stakeholders at all levels of the tourism industry-government, private enterprises, NGOs, and communities-to support rural women and men in identifying and capitalizing upon their own unique potential. This situation is evident throughout Africa, where propoor tourism initiatives have yet to forge the important links between higher education, communities, NGOs, and the tourism industry. This project provides means to overcome these limitations by developing leadership and human resource capacity at the university level to provide sustained training and integration at all these levels of the tourism industry so that best practices and lessons learned through the community tourism initiatives developed in this project can be integrated into the planning and management of subsequent tourism initiatives throughout Uganda. Before the curriculum development could be initiated, the partnerships needed to be secured.

To begin, a participatory rural appraisal process was undertaken both separately by Makerere University and jointly with the University of Manitoba in 2006-2007 to determine the three communities where the efforts of the project (i.e., strategic partnerships and student fieldwork placements) would focus. They are the village communities of Ruhija, Katanguru B, and KyanyawaraIbura adjacent to Bwindi, Queen Elizabeth, and Kibale National Parks, respectively. The details of this scoping stage of the project can be found in a separate document by the authors (in press). The scoping stage was followed by in-depth participatory rural appraisals of the shortlisted communities to identify community solidarity and resources to support field placements and partnerships. As a component of this stage, stakeholders were consulted widely to develop criteria for assessment and to identify training needs at all levels of the tourism industry. The partnership development process remains an ongoing process and challenge for the program, details of which are discussed below.

\section{Developing a Strategic Partners' Network}

Tourism in Uganda has recently overtaken all other sectors as the number one contributor to the GDP (personal communication with Minister of State for Tourism, 2008).

As noted in the tourism policy of 2004:

Interventions are required before the Uganda Wildlife Authority, through collaboration with the private sector, can ensure the necessary product development and product diversification envisaged as the basis for the tourism development strategy focusing on development of niche markets. Consequently, additional links and closer collaboration between UWA, UTB, and the private sector/developers are required. (Government of Uganda, 2004)

One means of initiating these needed partnerships is through the development of the tourism master's curriculum at Makerere University and the associated community placements, through in- 
volving the relevant stakeholders at all stages of the project development process. As can be seen from the schematic in Figure 1, the process of partnership development is an ongoing one with new partners being identified and invited to join as the work of the project progresses. In this manner all three main thrusts of the project are intimately linked and inform the progress of the others. The process of partner development at these early stages is strongly influenced by the time the Canadian partners (PI, team, and students) are able to spend in Uganda and model positive partner behaviors.

Despite the best efforts of the project team to include all relevant stakeholders, a number of challenges arose during the program development process. Indeed, project principals noted a significant degree of information "omission" on the part of project partners in identifying other potential partners. In one instance an alumnus of the University of Manitoba approached the project director (Canada) to indicate that she was to be working as a volunteer for a year with the Bwindi Mgahinga Conservation Trust (BMCT) and would like to know if there was an opportunity to cooperate with the CIDA project as the two shared similar goals and were operant in the same region of Uganda. The fact that this particular NGO was not brought to the project's attention by any of the partners (including NGO Forum, whose role it is to facilitate cooperation) illustrates the challenge that partnerships face in development projects such as this, where fears of potential loss of project funds, competition for other resources, and concerns over sharing "credit" for success may impede partnership development. In the end the project principals were able to overcome this by engagement of all potential partners in decision making, sharing credit and resources to ensure project success. This was accomplished, in part, by providing an intern to work with BMCT and the project for 4 months in 2008. Funding for the intern was secured by the Canadian project team through a Students for Development Grant and administrative support for the supervision of the student was provided to BMCT. In this manner the CIDA project demonstrated its commitment to the partnership and that it was willing to share resources. The internship identified areas in which
BMCT's expertise would benefit the community and support the CIDA project, thus assuring that both "partners" benefited and were credited with a portion of the success. As a result of this successful interaction, BMCT has joined the project advisory committee and is now actively engaged in project implementation by providing advice and training in sustainable agronomy and cultivar selection to take advantage of downstream linkages to the tourism initiatives. In addition, while still in the developmental stages BMCT and the regional government are cooperating in assessing the development of a clean water project for the community. Similarly, Peace Corps Volunteers in Queen Elizabeth National Park, Directors of the Chimp$\mathrm{N}-\mathrm{Sea}$ Conservation NGO and several other NGOs (large and small) have been identified as potential collaborators and partners, largely though serendipitous meetings in the field ${ }^{1}$. The University of Manitoba team's efforts at linking with these other potential partners has fostered a new attitude of cooperation within the stakeholders group that is slowly emerging. One key element in this has been the U of M's willingness to share knowledge and expertise broadly with potential partners, for example, providing a free GIS training workshop to any potential partner, even those that may perceive themselves as "competitive" projects. Since the inception of the project, annual stakeholder and advisory committee meetings have been held, well attended, and reflect the original members plus the addition of new project partners. Table 1 illustrates the original and current partners.

In addition to the Canadian student internships a key variable in maintaining and developing partnerships is the considerable amount of time and number of visits the Canadian partners spent in Uganda. Figure 2 illustrates to timeline a number of key activities that together with Figure 1 emphasizes the manner in which the three core thrusts of the program are integrated and support one another. In addition, it also provides an indication of the number of visits the $U$ of $M$ team made to Uganda (approximately five per year) spanning up to 3 months (student internships). As the project progressed, faculty found more frequent and shorter visits to be more effective in maintaining relationships and in identifying new ones.

Early during the consultation process, stake- 
Table 1

Project Partners

\begin{tabular}{lll}
\hline Original Partners & \multicolumn{1}{c}{ Current Partners } & \multicolumn{1}{c}{$\begin{array}{c}\text { Potential } \\
\text { Future Partners }\end{array}$} \\
\hline Makerere University $^{\mathrm{a}}$ & Makerere University & Chimp-N-Sea \\
UWA $^{\mathrm{b}}$ & UWA & $\begin{array}{l}\text { Chime Corp } \\
\text { PTB }\end{array}$ \\
UTA $^{\mathrm{c}}$ & Tourism Uganda & Biology Department \\
UCOTA & UTA & MUBFS \\
COBATI & UCOTA & MUBS \\
CARE & BMCT & Katunguru B \\
NGO-Forum & UFA & Ishasha Community \\
& MTTI & \\
& Ruhija Community & \\
\hline
\end{tabular}

UWA: Uganda Wildlife Authority; UTB: Uganda Tourist Board; UTA: Uganda Tourism Association; UCOTA: Uganda Community Tourism Association; COBATI: Community Based Tourism Initiative; BMCT: BwindiMgahinga Conservation Trust; UFA: Uganda Forest Authority; MTTI: Ministry of Tourism Trade and Industry; MUBFS: Makerere University Biological Field Station; MUBS: Makerere University Business School.

${ }^{a}$ Faculty of Veterinary Medicine: Wildlife and Animal Resource Management Department; Faculty of Forestry and Natural Resources; Faculty of Gender and Women's Studies; Department of Geography.

${ }^{\mathrm{b}}$ Geography Department no longer a partner.

${ }^{\mathrm{c}}$ Now Tourism Uganda.

holders identified field-based practical skills and practicum as missing elements in existing university programs. In addition, concerns were raised about the apparent inability of students to examine problems and develop solutions independently. Built in to the new curriculum is such a practicum aimed at linking students (and as a consequence the university) with NGOs, government departments, and communities that they serve. The new program's graduate students will work in poor rural communities adjacent to protected areas where their knowledge will be shared to assist villagers in generating healthy livelihoods through wildlife and community-based tourism and as a consequence motivating them to advocate for conservation.

\section{Curriculum Development: Masters in Wildlife}

Tourism and Recreation Management

The tourism policy (Government of Uganda, 2003) noted a deficit with respect to professional training in the tourism industry and in particular the ability to connect the current needs of tourists to the resources available. This shortcoming was also cited by industry representatives during the preliminary consultations and was most often identified as an inability to conceptualize and conduct research with respect to the tourist experience.

\section{Prior Training Opportunities}

Prior to the development of the master's program in Wildlife Tourism and Recreation Management there was an undergraduate degree (Bachelor of Arts) hosted in the Department of Geography at Makerere University and a Diploma in Tourism and Hospitality School in Jinja. In addition, students in the Wildlife and Animal Resource Management Department at Makerere University studied community-based conservation and, tangentially, the potential impact of tourism on wildlife, the environment, and communities. Results from the needs assessment conducted though the initial scoping process suggested that the current programs were not meeting the needs of a broad sector of the tourism industry. Specifically, the UWA, the Ministry of Tourism, Trade, and Industry, and UTB identified a lack of practical skills in current university tourism graduates and the need for a strong practical component in any curriculum de- 


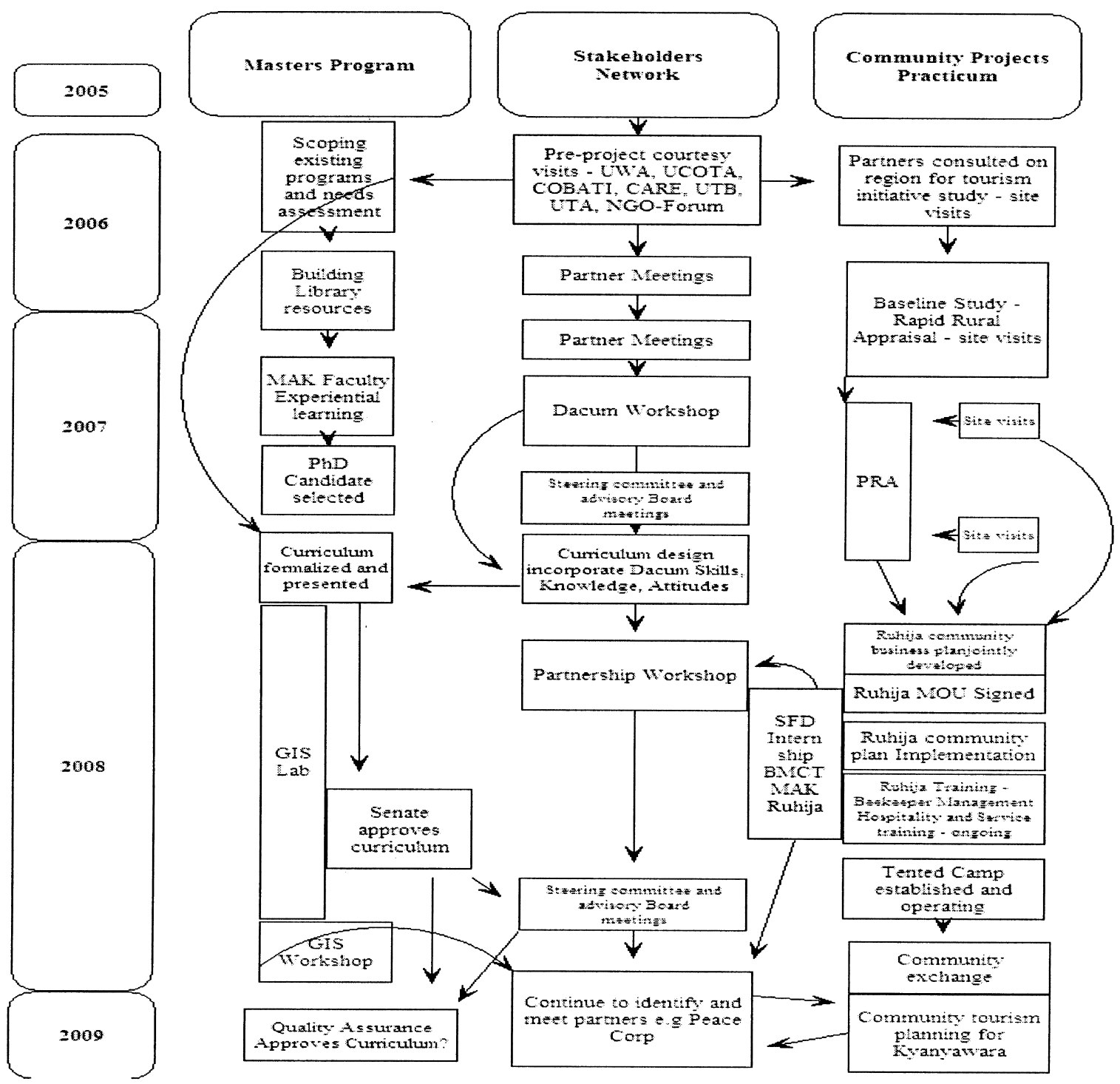

Figure 2. Project activity timeline showing selected activities, relationships, and number of interactions.

veloped. In addition, students expressed frustration with their inability to pursue graduate-level study to develop local educational and professional capacity.

Cooper (2002) highlights the progression of tourism curriculum development paralleling curriculum theory generally and moving from content focus to a process focus. This parallels the development of curricula that have followed the format of increasing industry involvement in identifying the types of knowledge, skills, and attitudes that graduates should hold upon completion of their degree and for entry into the workforce (Clark \& Arbel, 1993; Marsh, 2000; van Horen, Leaf, \& Pinnawala, 2004). Thus, the questions become: What do students want? What does the industry want? What does the University want? (Cooper, 2002). The process by which these questions were answered in this case followed the Dacum process (Coffin, 1993) and incorporated elements of a Del- 
phi approach, where industry expertise was solicited for input into the curriculum prior to the formal Dacum process (Dalkey, 1969). The Delphi approach has been used extensively in resource management, for example to identify wildlife habitat requirements (Crance, 1987), determine critical factors associated with sustainable tourism (Spencely, 2008), and for environmental assessment (Ritchey, Mar, \& Horner, 1985). The process seeks input of experts to gain consensus while avoiding the potential for groupthink. In seeking to initiate cooperation across constituencies in Africa it is important to recognize potential barriers to full incorporation of partner ideas in the development model. Tribe (2003) cautions against the strategic management approach to curriculum design where the views of partners external to the university may be downgraded and marginalized. This was particularly relevant in this case where the academic culture is very hierarchical and there was some attempt to propose a curriculum in advance of the Dacum process. As a result, ensuring adherence to the design process so that all partners' views were incorporated into the curriculum design was a challenge faced by the academic partnership. The application of the Dacum process, which focuses upon the skills, attitudes, and knowledge industry and other potential employers require of graduates, rather than the select courses to be offered as the entry to curriculum development, greatly assisted in reducing the influence of said hierarchies.

Over the course of 3 days in 2007, representatives from a number of tourism sectors, government, tourism-related NGOs, students, and university faculty (Table 2) met to identify the skills, knowledge, and attitudes deemed necessary and desirable for graduates of the proposed wildlife tourism and recreation management graduate program. Notable is the multidisciplinary perspectives represented by the university faculty and students: recreation, environment, forestry, veterinary medicine, geography, and wildlife. The workshop itself was conducted by representatives of the University of Manitoba and facilitated in an interactive and adaptive manner (Nelson, 1994).

Results of the individual brainstorming sessions to elicit desired skills, knowledge, and attitudes/ traits of graduates were recorded, synthesized to eliminate duplication, and prioritized through a weighting process based upon the input of the participants. Fourteen key areas were identified: resource management; entrepreneurship; communities and tourism; policy and legislation; product development; marketing; planning; health and safety; research; interpretation/guiding; hospitality; gender; management and finance; and communication. The information about skills, knowledge, and attitudes was transcribed and presented to the group at the beginning of the next day to ensure that the information recorded reflected the discussions. Following agreement on the information as transcribed, the group was then asked to process the list to identify and rank the information to arrive at a list that focused upon the critical areas of knowledge, skills, and attitudes. Each of these is described briefly below.

\section{Resource Management}

This would require training in resource economics, biodiversity conservation, anthropology, and ability to resolve natural resource conflicts. Graduates should be able to change attitudes and

\section{Table 2}

Participants in DACUM Tourism Curriculum Development

\begin{tabular}{|c|c|c|c|c|}
\hline Industry Representatives & Public Sector Representatives & $\begin{array}{c}\text { Students } \\
\text { (Faculties/Dept.) }\end{array}$ & $\begin{array}{c}\text { University } \\
\text { Departments }\end{array}$ & NGOs \\
\hline $\begin{array}{l}\text { Accommodations owner } \\
\text { Uganda Tourism Association } \\
\text { Uganda Tourism Board } \\
\text { Uganda Tour Guides Association }\end{array}$ & $\begin{array}{l}\text { Uganda Wildlife Authority } \\
\text { Ministry of Tourism, Trade \& Industry } \\
\text { UWA Field Staff } \\
\text { Ministry of Environment }\end{array}$ & $\begin{array}{l}\text { Wildlife Mgmt. } \\
\text { Geography } \\
\text { Forestry } \\
\text { Gender } \\
\text { Zoology }\end{array}$ & $\begin{array}{l}\text { Wildlife } \\
\text { Geography } \\
\text { Veterinary } \\
\text { Forestry } \\
\text { Environment } \\
\text { Recreation }\end{array}$ & $\begin{array}{l}\text { UCOTA } \\
\text { NGO Forum } \\
\text { Care Uganda }\end{array}$ \\
\hline
\end{tabular}


behaviors of local communities around protected areas towards biodiversity conservation. They should also be able to add value to identified tourism resources, identify and manage tourist health, safety, and security issues.

\section{Entrepreneurship}

Graduates should be able to add value to the tourism experience thus create the ultimate expedition. The graduates should be able to initiate and manage tourism ventures. Good public relations are mandatory for this particular field to start and market tourism.

\section{Communities and Tourism}

The master's program should produce leaders and advocates of tourism, information providers or consultants, tour operators, and resource interpreters. Graduates should be able to demonstrate to local communities the benefits of tourism, apply modern concepts of tourism, and promote conservation of natural resources outside protected areas.

\section{Policy and Legislation}

Graduates should be able to engage in tourism policy development and execution and should understand the leadership structures at local, national, and international levels. Graduates should be able to evaluate the effectiveness of policy and modify as necessary.

\section{Product Development}

Graduates should be able to identify viable tourism products, develop them by adding value, package them, and eventually be able to bring them to market.

\section{Marketing}

Graduates should be able to identify and develop tourism resources, have knowledge of product packaging and designing to attract a bigger market. They should be persuasive or have good bargaining skills. The marketing area relates more to goods and services and not to destinations/communities, per se.

\section{Planning}

Participants wanted the graduates to have planning skills for community partnership development and also be resource managers. They should also be able to develop tourism management systems. Graduates should be able to understand the link between natural resources and development and have land use planning and management skills. In addition, they should be able to do site planning.

\section{Health, Safety, and Security}

The health of communities where tourist activities are concentrated is important to the health of the tourists. This therefore entails issues of public health and safety and mandatory first aid. Issues like bioterrorism should also be addressed in this section.

\section{Research}

Keeping statistics, monitoring, and impact assessment were all included in the research area. Graduates should be able to assess the negative and positive impacts of tourism on the poor/propoor tourism and on communities. They should be able to monitor, evaluate, and produce concrete data on the results found and be able to publish those findings for the tourism sector. They should also be able to source or lobby for funds for research and implementation of projects. Understanding tourist needs, motives, and wants and their application to marketing were also deemed to be important skills.

\section{Guiding/Interpretation}

Graduates should be able to do nature interpretation, have technical skills, first aid, and environmental education background.

\section{Hospitality}

Empathy, kindness, welcoming, outgoing nature, and honesty were some of the traits the graduates must have to attract tourists and keep them. This will encourage a bigger market even when these tourists go back to their countries; they keep referring others to a place where they were treated well. 


\section{Gender}

The program should involve both women and men in tourism activities, tourism training for different professions, and produce more tourism educators. Graduates should consider new approaches to tourism and minimize sex tourism and prostitution. Gender sensitivity is required.

\section{Management/Administration/Finance}

Graduates should be able to work in government departments such as the tourism ministry and other administrative institutions to develop policies, programs, and implement them. They must have management skills for people (human resources) and financial resources.

\section{Communication}

Language skills are important to target different tourists of different origins. In addition, graduates must be good listeners and fluent in the local languages to identify easily with the communities.

Capturing the scope of knowledge, skills, and attitudes expressed by the working group in a graduate curriculum was the next step in the process. This was undertaken by the academic staff from Makerere University and University of Manitoba. The work was initiated in Uganda and then continued in a series of curriculum development meetings conducted during a visit of the Makerere faculty members to Manitoba. The challenge was ensuring the input of stakeholders was respected, while adhering to curriculum and course regulations and guidelines imposed by a university system. The result of this stage was again vetted through the Dacum committee members to ensure that no key areas were missed. From this the recommended core curriculum course outlines were produced for consideration by the Makerere University approval bodies. The proposed curriculum is detailed in Table 3.

As a consequence of the review by the relevant academic bodies at Makerere, the curriculum underwent several revisions and a change in its original name (working title was: Master of Sustainable Community Tourism) to reflect the hosting department (Wildlife and Animal Resource Management) and to allay concerns from the geogra- phy department so as not to preclude their ability to develop their own complementary program. The Wildlife Tourism and Recreation Management master's degree was approved by Senate in September 2008 and now sits before the Quality Assurance Board of Makerere University.

\section{Conclusion}

As conceived, the curriculum provides the vehicle for action learning with the rural communities around protected areas of Bwindi, Queen Elizabeth, and Kibale National Parks forming the life laboratories or workshops for developing/transferring skills, and learning tourism best practices while serving as a rich database in indigenous knowledge and cultures. The curriculum also helps to draw together all key players in wildlife and community tourism-NGOs, local government, line ministries, conservationists, tourism board, tourism association, UWA - to work together with students and university faculty to harness this valuable resource in sustainable manner. The model adopted herein demystifies universities as the "Ivory Tower" devoid of shared vision for rural community development concepts. Instead, the rural communities and the protected ecosystems serve as attractive centers for innovations in tourism, learning, knowledge creation, and economic development. Finally, as tourism is still a relatively nascent industry in Uganda, the education of tourism professionals capable of anticipating and managing a growing number of visitors is essential to ensure the sustainable planning and management of the developing industry.

In combination with the emerging strategic stakeholders' network the project addresses key concerns of positive pro-poor tourism, such as enhancing forward and backward linkages (e.g., linking agricultural innovation to tourism, exporting crafts to Canadian facilitating NGOs). To date, while no graduate students from the proposed new program have been on a community field work placement, there have been opportunities for students from the University of Manitoba to engage in international practicum. This has provided a "pilot project" of sorts and demonstrated the potential for the program aims to be realized. For example, $\mathrm{U}$ of $\mathrm{M}$ students have worked on design 
Table 3

Proposed Curriculum for Master of Wildlife Tourism and Recreation Management

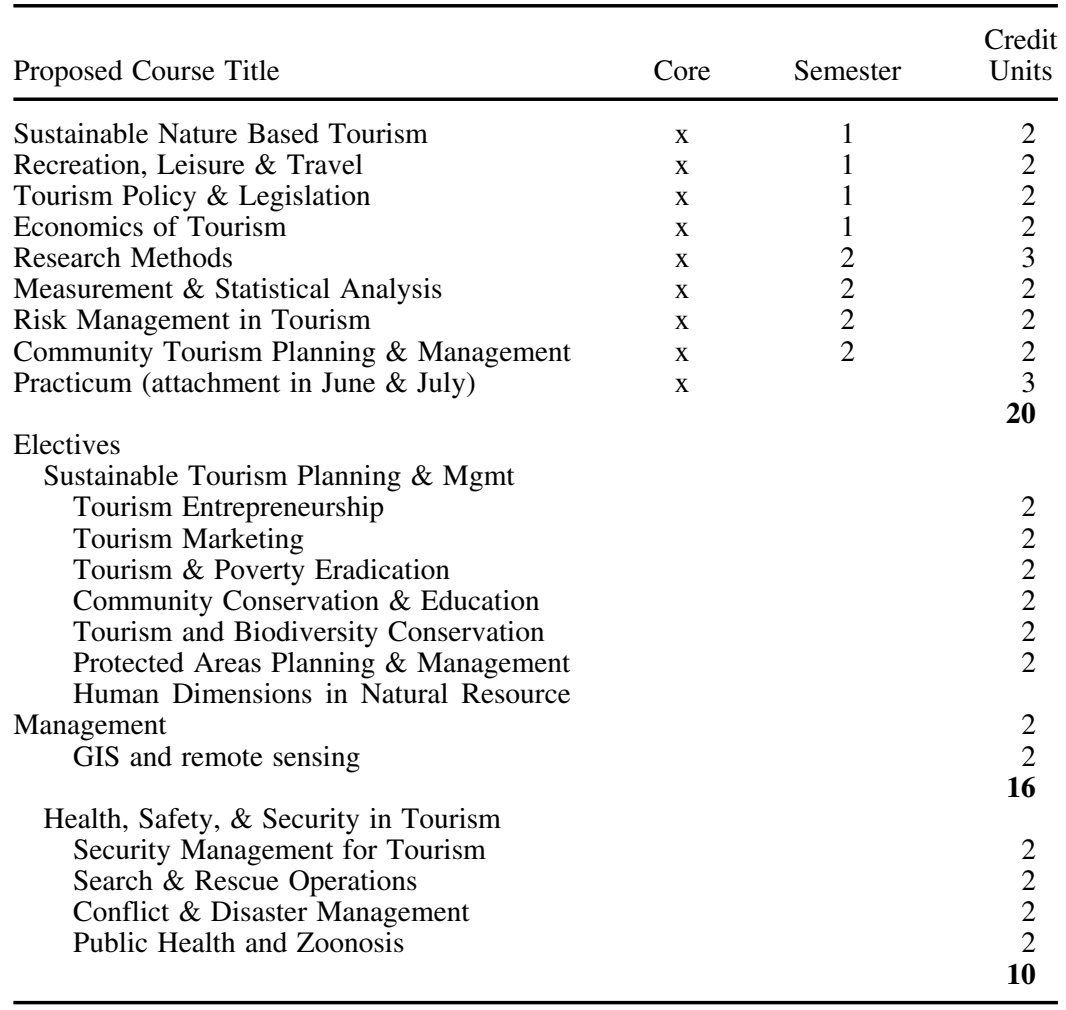

of tourist accommodations, and through existing NGOs initiated beekeeper training of Ruhija community members and development of collective community income through tourism based activities (e.g., selling honey and beeswax products; building tourist camps) and improving access to services and infrastructure through engagement of local council and industry (Momsen, 2003).

Despite the early successes of the project it has not been without its challenges. As indicated earlier, a significant challenge has been that of identifying and contacting potential partners through our southern partners. There appears to be some overt omission of information regarding potentially cooperating organizations. This reflects a number of underlying concerns the southern partners have vis-à-vis control of the project and its resources, concerns about credit for ideas, work, etc., and the expectation of payment for attending meetings, which is fairly strongly entrenched in the country. In addition to the aforementioned, internal politics at Makerere resulted in significant delays in the program approval process. In the end, one of the original partnering departments chose to leave the project and try to develop a separate program. At the moment the Makerere University Business School (MUBS) has been loosely involved and may become a full partner in the future. These experiences underscore that in this context, partnership is indeed an approach and not a product (Scheyvens, 2007).

Optimism for successful realization of project goals, particularly enhanced rural livelihoods through education and strategic partnerships, is high. Over the course of the next year the curriculum will be implemented and an initial intake of 10 students will begin the master's program. Two new community tourism initiatives will begin over the next 18 months, providing placements for Wildlife Tourism and Recreation Management graduate students and income for rural people. The Uganda case study presented here provides sup- 
port for noted pro-poor tourism principles (Chok et al., 2007) that recognize the need to be context specific, have both macro- and microapproaches, draw on cross-disciplinary learning, and, most of all, be flexible.

\section{Note}

${ }^{1}$ A Peace Corp volunteer working on community tourism in QENP was brought to the teams attention AFTER the team had left the park, despite the fact that the volunteer was in the main office at the time of our visit, was without transport, and we were engaging communities to discuss community tourism potential. Subsequently, we were able to contact the volunteer and are hoping to initiate a mutually beneficial situation.

\section{References}

Ashley, C., Roe, D., \& Goodwin, H. (2001). Pro-poor tourism strategies: Making tourism work for the poor. A Review of experience. London: Overseas Development Institute.

Chok, S., Macbeth, J., \& Warren, C. (2007). Tourism as a tool for poverty alleviation: A critical analysis of propoor tourism and implications for sustainability. In C. Michael Hall (Ed.) Pro-poor tourism: Who benefits? Perspectives on tourism and poverty reduction (pp. 3455). Clevedon, UK: Channel View Publications.

Clark, J. J., \& Arbel, A. (1993). Producing global managers: The need for a new academic paradigm. The Cornell Hotel and Restaurant Administration Quarterly, 34(4), 83-89.

Coffin, L. (1993). The DACUM facilitator's manual. Charlottetown, PEI: Glendinning Educational Resources.

Cooper, C. (2002). Curriculum planning for tourism Education: From theory to practice. Journal of Teaching in Travel \& Tourism, 2(1), 19-29.

Crance, J. H. (1987). Guidelines for using the Delphi technique to develop habitata suitability index curves. US Department of the Interior. Washington, DC. Biological Report, 82(10), 134.

Dalkey, N. C. (1969). The Delphi method: An experimental study of group opinion. Santa Monica, CA: Rand Corporation.

de Kadt, E. (1979). Tourism: Passport to development. Perspectives on the social and cultural effects of tourism in developing countries. New York: Oxford University Press.

Government of Uganda (2000). Development poverty reduction strategy paper Uganda's poverty eradication action plan. Kampala, Uganda: Ministry of Finance, Planning and Economic Summary, and Main Objectives.
Government of Uganda. (2003). Tourism policy for Uganda. Kampala, Uganda: Ministry of Tourism, Trade, and Industry.

Government of Uganda. (2004). Sustainability initiatives for the Uganda wildlife authority (Draft). Kampala, Uganda: Uganda Wildlife Authority.

Hall, C. M. (Ed.). (2007). Pro-poor tourism: Who benefits? Perspectives on tourism and poverty reduction. Clevedon, UK: Channel View Publications.

Marsh, C. (2000). End user computing at a South African Technikon: Enabling disadvantaged students to meet employers' requirements. In European Conference on Educational Research, Edinburgh Scotland, September $20-23$.

Momsen, J. H. (2003). Participatory development and indigenous communities in the Mexican Caribbean. In J. Pugh \& R. Potter (Eds.), Participatory and communicative planning in the Caribbean (pp. 155-172). Aldershot: Ashgate.

Nelson, J. G. (1991). Research in human ecology and planning: An interactive, adaptive approach. The Canadian Geographer, 35(2), 114-127.

Ritchey, J. S., Mar, B. W., \& Horner, R. R. (1985). The Delphi technique in environmental assessment. Journal of Environmental Management, 21(2), 135-146.

Scheyvens, R. (2007). Exploring the tourism poverty nexus. In C. Michael Hall (Ed.) Pro-poor tourism: Who benefits? Perspectives on tourism and poverty reduction ( $\mathrm{pp}$. 121-144). Clevedon, UK: Channel View Publications.

Scheyvens, R., \& Momsen, J. H. (2008). Tourism and poverty reduction: Issues for small islands. Tourism Geographies, 10(1), 22-41.

Spenceley, A. (2008). Requirements for sustainable naturebased tourism in Transfrontier conservation areas: A southern African Delphi consultation. Tourism Geographies, 10(3), 285-311.

Tribe, J. (2003). Curriculum, development, and conflict: A case study of Moldova. Journal of Teaching in Travel and Tourism, 3(1), 25-45.

United Nations Development Programme. (2004). 2015: Mobilizing partnerships: United Nations Development Program annual report. New York: Author.

van Horen, B., Leaf, M., \& Pinnawala, S. (2004). Localizing global discipline: Designing new planning programs in Sri Lanka. Journal of Planning Education and Research, 23, 255-268.

World Bank (2003). World development report 2003: Sustainable development in a dynamic world, transforming institutions, growth and quality of life. New York: World and Bank and Oxford University Press.

Zhao, W. \& Ritchie, J. R. B. (2007). Tourism and poverty alleviation: An integrative research framework. In C. Michael Hall (Ed.) Pro-poor tourism: Who benefits? Perspectives on tourism and poverty reduction (pp. 933). Clevedon, UK: Channel View Publications. 